\title{
Pneumococcal meningitis and COVID-19: dangerous coexistence. A case report
}

\author{
Katarzyna Guziejko ${ }^{* *}$, Piotr Czupryna² Ewa Katarzyna Zielenkiewicz-Madejska ${ }^{3}$ and \\ Anna Moniuszko-Malinowska²
}

\begin{abstract}
Background: SARS-CoV-2 is the major cause of infections in humans since December 2019 and is top of the global health concern currently. Streptococcus pneumoniae is one of the leading pathogens of invasive bacterial diseases, including pneumonia, sepsis, and meningitis. Moreover, this bacteria is mostly responsible for secondary infections subsequent to post-viral respiratory disease. Co-infections with bacterial and viral pathogens are associated with severe course of the disease and are a major cause of mortality. In this report, we describe a rare case of COVID-19 patient with pneumococcal sepsis and meningitis of unsuccessful course.
\end{abstract}

Case presentation: A 89-year-old man, not vaccinated against SARS-CoV-2 infection, was diagnosed with COVID-19 pneumonia. Patient required oxygen therapy due to respiratory failure. The initial treatment of viral infection with tocilizumab and dexamethasone allowed for the stabilization of the patient's condition and improvement of laboratory parameters. On the 9th day of hospitalization the patient's condition deteriorated. Consciousness disorders and acute respiratory disorders requiring intubation and mechanical ventilation were observed. Brain computed tomography excluded intracranial bleeding. The Streptococcus pneumoniae sepsis with concomitant pneumoniae and meningitis was diagnosed based on microbiological culture of blood, bronchial wash, and cerebrospinal fluid examination. Despite targeted antibiotic therapy with ceftriaxone and multidisciplinary treatment, symptoms of multiple organ failure increased. On the 13th day of hospitalization, the patient died.

Conclusions: Co-infections with bacterial pathogens appear to be not common among COVID-19 patients, but may cause a sudden deterioration of the general condition. Not only vascular neurological complications, but also meningitis should be always considered in patients with sudden disturbances of consciousness. Anti-inflammatory treatment with the combination of corticosteroids and tocilizumab (or tocilizumab alone) pose a severe risk for secondary lethal bacterial or fungal infections. Thus, treating a high-risk population (i.e. elderly and old patients) with these antiinflammatory agents, require daily clinical assessment, regular monitoring of C-reactive protein and procalcitonin, as well as standard culture of blood, urine and sputum in order to detect concomitant infections, as rapidly as possible.

Keywords: COVID-19, Streptococcus pneumoniae, Meningitis, Sepsis, Co-infection

*Correspondence: kguziejko@wp.pl

1 2nd Department of Lung Diseases and Tuberculosis, Medical University

of Bialystok, Żurawia 14, 15-540 Białystok, Poland

Full list of author information is available at the end of the article

\section{Background}

From December 2019, coronavirus disease-2019 (COVID-19) caused by a newly discovered coronavirus (severe acute respiratory syndrome coronavirus-2, SARS-CoV-2), is not only the most common infectious disease, but also the major concern of global health $[1,2]$. Streptococcus pneumoniae (S. pneumoniae), along with Haemophilus influenzae (H. influenzae) and Neisseria 
meningitidis ( $N$. meningitidis), are the main pathogens of most cases of invasive bacterial diseases, including pneumonia, sepsis and meningitis [3, 4]. Based on the studies conducted so far during influenza virus pandemic, $S$. pneumoniae has been proven to be mostly responsible for secondary infections subsequent to post-viral respiratory disease [5-7]. The incidence of co-infections with bacterial and viral pathogens are estimated at 3-8.6\%. However, their clinical course is associated with severe symptoms and is the major cause of mortality [8-10].

In this report, we present a rare case of patient with COVID-19, pneumococcal sepsis and meningitis of unsuccessful course. No symptoms of invasive bacterial co-infection were found during admission of patient to the hospital. Deterioration of the general condition and the occurrence of disturbances of consciousness required a differential diagnosis between the neurological complications of COVID-19 and neuroinfection. Despite early diagnosis and appropriate treatment, the course of viral and bacterial co-infection was fatal in the described case.

\section{Case presentation}

A 89-year-old male patient, farmer, not vaccinated against COVID-19, was admitted to the Observation and Infectious Diseases Department District Hospital due to fever, cough, weakness, and low exercise tolerance. Symptoms exacerbated during last 14 days prior to hospitalization. He was treated empirically with oral antibiotics in standard doses (amoxicillin and clavulanic acid, levofloxacin) without clinical improvement. Rapid test for qualitative detection of SARS-CoV-2 antigen (Panbio $^{\mathrm{TM}}$ COVID-19 Ag Rapid Test Device, Abbott), performed from nasopharyngeal swabs during admission in the Emergency Room, was positive. In medical history patient reported bronchial asthma, hypertension, and heart failure. No neurodegenerative condition or dementia have been diagnosed previously.

During admission, the patient was conscious and in logic contact. Physical examination revealed dehydration, prolonged exhalation phase, numerous crackles and single wheezes during lung's auscultation, finger pulse $\mathrm{SpO} 2$ was $85 \%$ without oxygen supplementation. Laboratory tests showed increased concentration of C-reactive protein (CRP) with normal procalcitonin (PCT) values, high interleukin 6 (IL-6) and lactic acid value, increased activity of transaminases (Table 1). Severe hypoxemia was found in blood gas analysis. The chest X-ray revealed bilateral, diffused interstitial opacities, especially in the left lower lobe (Fig. 1). High resolution computed tomography (HRCT) of chest confirmed typical for COVID-19 pneumonia radiological findings. In total, right lung was affected in $40 \%$, and the left in $60 \%$ (Fig. 2). The treatment included tocilizumab (single dose of $600 \mathrm{mg}$ ), low molecular weight heparin (enoxaparin $1 \mathrm{mg}$ per kg bodyweight daily), glucocorticosteroids (dexamethasone $6 \mathrm{mg}$ per day), bronchodilators (SABA + SAMA), fluid therapy, passive oxygen therapy via a mask with an oxygen reservoir with a flow of $6 \mathrm{~L} / \mathrm{min}$. Stabilization of the patient's condition, normalization of blood saturation and inflammatory parameters in laboratory tests were achieved (Table 1). Fever was not observed.

On the 9th day of hospitalization, in the early morning hours, the patient's condition deteriorated. He was unconscious, with no reaction to external stimuli, rated at 5 points on the Glasgow scale. The physical examination revealed fever up to $38.2{ }^{\circ} \mathrm{C}$, tachypnea (respiratory rate was 30 breaths per minute), high blood pressure values, right hemiparesis, the neck stiffness, a positive Babinski sign on the right sight. Due to the suspicion of a stroke, resulting from thromboembolic complications of COVID-19, a brain CT was performed. No signs of intracranial bleeding were observed (Fig. 3). Laboratory tests revealed a significant increase in inflammatory parameters (Table 1). Blood and urine samples were collected for microbiological tests. Empirical antibiotic therapy with ceftriaxone ( $2 \mathrm{~g}$ twice a day intravenously) and ciprofloxacin (400 mg twice a day intravenously) was implemented. Six hours after the onset of consciousness disturbances, the patient developed apnea. He was intubated and mechanical ventilation was started. Control brain CT performed $12 \mathrm{~h}$ after first brain imagining excluded intracranial hemorrhage. Blood and the bronchial wash cultures were positive for S. pneumoaniae after $48 \mathrm{~h}$. Minimum inhibitory concentration (MIC) for ceftriaxone was $\leq 0.12 \mu \mathrm{g} / \mathrm{mL}$. Urine culture was negative. Lumbar puncture was performed after stabilization of the patient's condition. Based on the result of the cerebrospinal fluid (CSF) tests, bacterial neuroinfection was confirmed (Table 2). CSF culture was negative. No PCR and rapid latex agglutination tests of CSF were performed because of the small amount of the collected fluid. Despite the multidisciplinary treatment, the patient's condition deteriorated. Symptoms of multiple organ failure increased. On the 13th day of hospitalization, the patient died.

\section{Discussion and conclusions}

COVID-19 pneumoniae and the respiratory failure are the most common clinical manifestations among hospitalized patients with SARS-CoV-2 infection. Complications of COVID-19 include ARDS, sepsis, septic shock, coagulopathy, acute cardiac injury, renal failure $[1,2]$.

The increasing prevalence of neurological manifestations and complications associated with COVID-19 have been also observed. Current literature suggests that gustatory and olfactory dysfunctions, myalgia, headache, 
Table 1 Results of laboratory tests

\begin{tabular}{|c|c|c|c|c|c|c|c|}
\hline Day of hospitalization & 1 & 7 & 9 & 9 & 10 & 11 & 12 \\
\hline $\begin{array}{l}\mathrm{CRP}[\mathrm{mg} / \mathrm{l}] \\
\text { Normal range }<0.5 \mathrm{mg} / \mathrm{l}\end{array}$ & 76.23 & 4.09 & 53.26 & 62.77 & 107.99 & 91.56 & 51.15 \\
\hline $\begin{array}{l}\mathrm{PCT}[\mathrm{ng} / \mathrm{ml}] \\
\text { Normal range }<0.5 \mathrm{mg} / \mathrm{l}\end{array}$ & 0.16 & - & 0.85 & 2.61 & 8.7 & 13.07 & 8.37 \\
\hline $\begin{array}{l}\text { WBC count }[\text { cells } / \mu l] \\
\text { Normal range } 4.0-10.0 \times 10^{3} / \mu \mathrm{l}\end{array}$ & 7.3 & 13.47 & 26.0 & 22.98 & 22.99 & 21.25 & 16.30 \\
\hline 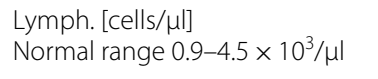 & 0.3 & 0.22 & 0.78 & 0.19 & 1.15 & 0.36 & 14.79 \\
\hline $\begin{array}{l}\text { Neutr. [cells/ } / \mathrm{l} \text { ] } \\
\text { Normal range } 1.8-7.7 \times 10^{3} / \mu \mathrm{l}\end{array}$ & 5.7 & 12.45 & 24.18 & 21.9 & 20.69 & 19.59 & 0.32 \\
\hline $\begin{array}{l}\text { RBC count }[\text { cells/ } / \mu l] \\
\text { Normal range } 4.63-6.08 \times 10^{6} / \mu \mathrm{l}\end{array}$ & 5.68 & 5.0 & 5.55 & 5.15 & 5.03 & 4.66 & 4.7 \\
\hline $\begin{array}{l}\mathrm{HGB}[\mathrm{g} / \mathrm{dl}] \\
\text { Normal range } 14.00-18.00 \mathrm{~g} / \mathrm{dl}\end{array}$ & 16.2 & 14.5 & 16.4 & 15.0 & 14.6 & 13.7 & 13.6 \\
\hline $\begin{array}{l}\text { PLT count [cells } \times 103 / \mu l] \\
\text { Normal range } 150-400 \times 10^{3} / \mu l\end{array}$ & 218 & 245 & 258 & 233 & 161 & 150 & 129 \\
\hline $\begin{array}{l}\text { AlAT }[\mathrm{IU} / \mathrm{l}] \\
\text { Normal range }<41 \mathrm{IU} / \mathrm{I}\end{array}$ & 54 & 45 & 32 & 24 & 35 & 38 & 39 \\
\hline $\begin{array}{l}\text { AspAT [IU/I] } \\
\text { Normal range }<35 \mathrm{IU} / \mid\end{array}$ & 57 & 26 & 24 & 19 & 69 & 57 & 41 \\
\hline $\begin{array}{l}\text { GLUC [mmol//] } \\
\text { Normal range } 4.6-6.4 \mathrm{mmol} / \mathrm{l}\end{array}$ & 8.5 & 7.0 & 11.0 & - & 10.1 & - & 15.3 \\
\hline $\begin{array}{l}\text { Lactic acid }[\mathrm{mmol} / \mathrm{l}] \\
\text { Normal range } 0.5-2.2 \mathrm{mmol} / \mathrm{l}\end{array}$ & 3.4 & - & 3.0 & - & 3.2 & - & 4.2 \\
\hline $\begin{array}{l}\text { CREA }[\mathrm{ml} / \mathrm{ml}] \\
\text { Normal range } 0.7-1.2 \mathrm{mg} / \mathrm{l}\end{array}$ & 1.19 & 0.79 & 1.12 & 1.55 & 3.23 & 4.52 & 5.00 \\
\hline $\begin{array}{l}\text { D-dimer }[\mu \mathrm{g} / \mathrm{ml}] \\
\text { Normal range }<0.5 \mu \mathrm{g} / \mathrm{ml}\end{array}$ & 2.09 & 1.89 & 4.35 & 15.69 & 37.36 & 7.51 & 3.76 \\
\hline $\begin{array}{l}\text { IL-6 }[\mathrm{pg} / \mathrm{ml}] \\
\text { Normal range }<7.0 \mathrm{pg} / \mathrm{ml}\end{array}$ & 119.2 & - & - & - & - & - & - \\
\hline
\end{tabular}

CRP C-reactive protein, $P C T$ procalcitonin, WBC white blood cell count, Lymph. lymphocyte count, Neutr. neutrophil count, $R B C$ red blood cell count, $H G B$ hemoglobin, PLT platelets count, AIAt alanine aminotransferase, AspAt aspartate aminotransferase, GLUC glucose concentration, CREA creatinine, D-dimer fibrin degradation product, IL-6 interleukin 6

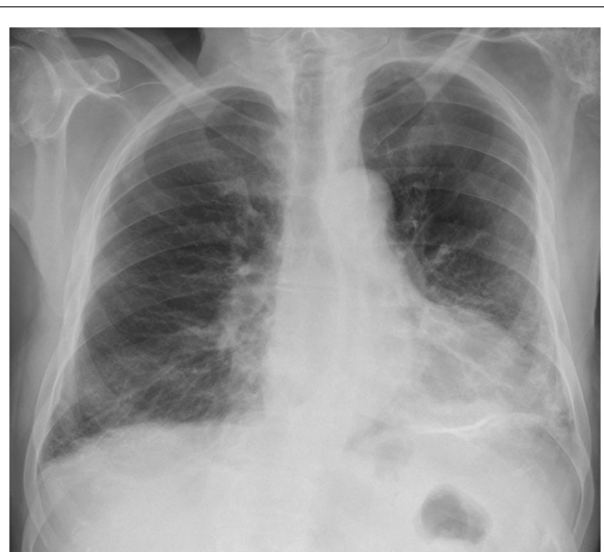

Fig. 1 Chest $x$-ray: bilateral, diffused interstitial opacities in lower lobes, especially by the left side altered mental status, confusion, delirium, dizziness, nausea and vomiting, as well as stroke, cerebral venous thrombosis, seizures, meningoencephalitis, GuillainBarré syndrome are most common neurological symptoms and manifestations in COVID-19 patients [11]. They can occur prior, during, and even after acute phase of SARS-CoV-2 infection [12].

However, in the presence of life-threatening respiratory failure in critically ill COVID-19 patients, neurological manifestations are usually undiagnosed [13]. In our case, the cause of sudden worsening of the neurological symptoms and the deterioration of the patient's condition was meningitis. Microbiological cultures of various samples and CSF examination resulted in early confirmation of neuroinfection. Simultaneous imaging of the brain excluded vascular complications, which may also appear in the course of SARS-CoV-2 infections [12].

Streptococcus pneumoniae is one of leading pathogens of invasive bacterial diseases, including pneumonia, sepsis, and meningitis. $[3,4]$. This pathogen is responsible 

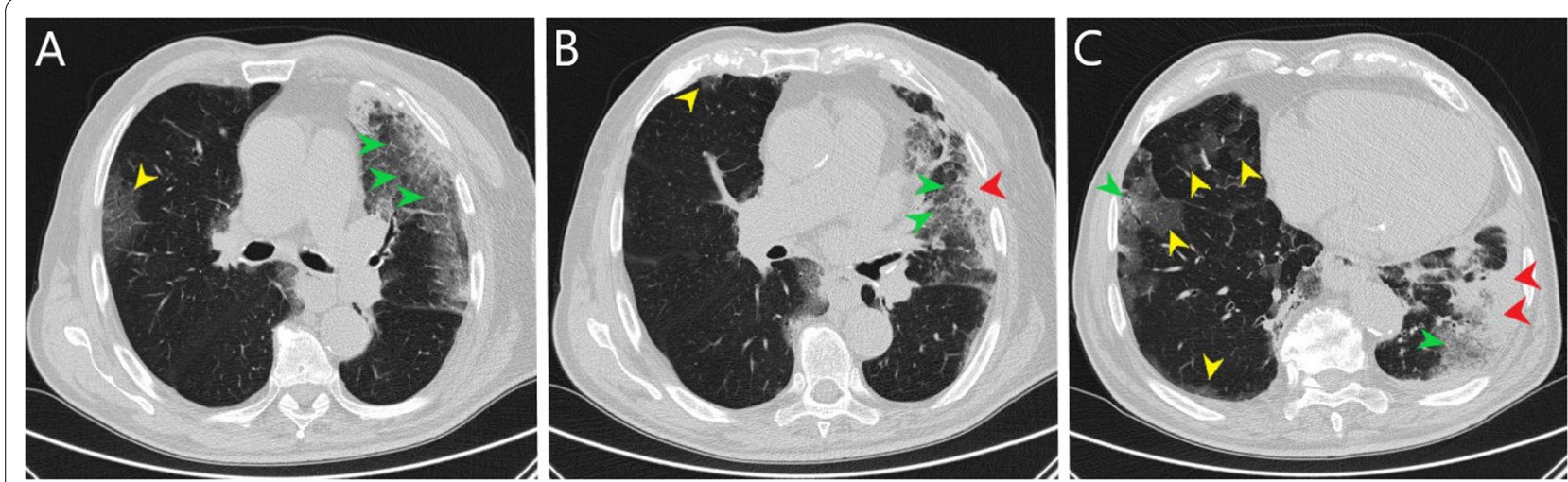

Fig. 2 Chest high resolution computed tomography (A-C lung window, axial scans): bilateral, predominately peripheral, ground-glass opacities (yellow arrowheads), crazy paving (green arrowheads) and consolidations (red arrowheads) especially in left lower lobe

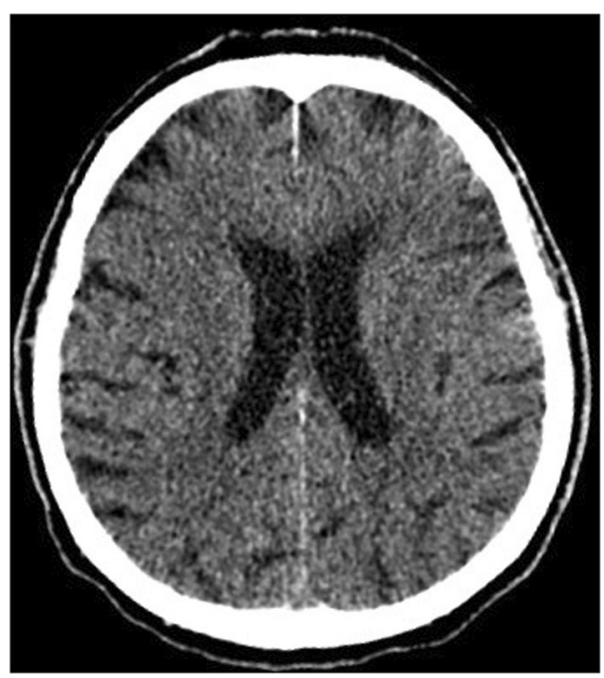

Fig. 3 Brain computed tomography (axial scan): no evidence of intracranial hemorrhage. Features of leukoaraiosis. Ventricles of normal volume. Brain structures without displacement. Skull bones in the study area without traumatic injuries

Table 2 Results of CSF examination

\begin{tabular}{|c|c|c|}
\hline Parameter & Result & Normal range \\
\hline 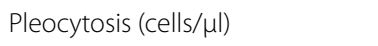 & 2420 & $0-5$ \\
\hline Lymphocytes (\%) & 5 & \\
\hline Granulocytes (\%) & 86 & \\
\hline Monocytes (\%) & 6 & \\
\hline Macrophages (\%) & 3 & \\
\hline Protein concentration (mg/dl) & 428.9 & $15.00-45.00$ \\
\hline Glucose concentration (mmol/l) & 4.71 & $2.22-3.89$ \\
\hline CSF culture & no growth & \\
\hline
\end{tabular}

for $25.1-41.2 \%$ of meningitis cases among all age groups. This clinical manifestation of bacterial infection is burdened with high mortality. Early diagnosis and the initiation of therapy significantly affect the course of the disease. Untreated properly, can be fatal in most cases [4].

Brueggemann et al. compared the incidence of invasive bacterial infection with S. pneumoniae, $H$. influenzae, and $N$. meningitidis during the COVID-19 pandemic in 26 countries with rates in previous years. They confirmed a significant reduction in invasive diseases in early 2020 . The incidence of reported S. pneumoniae infections decreased by $68 \%$ at 4 weeks since the pandemic restrictions were introduced for global scale [14]. Despite the decrease in the incidence of bacterial invasive infection, the suspicion of meningitis should be taken into account in the differential diagnosis of a disturbed consciousness, accompanied by acute respiratory failure, fever and a significant increase of inflammatory parameters. The clinical course of the neuroinfection was so severe in our patient, that mechanical support of ventilation was necessary to stabilize the patient's condition. Only then, after exclusion of cerebral edema in CT scans, it was possible to perform a lumbar puncture to confirm meningitis.

Coronaviruses are known for their neurological tropism. Numerous reports based on previous SARS-CoV and MERS-CoV epidemics, provide clear evidence of various neurologic sequalae (i.e. encephalitis, seizures, encephalopathy, Guillain-Barre syndrome), which may occur in association with respiratory symptoms [15, 16]. Neuroinvasion may take the form of viral encephalitis, confirmed by the presence of viral RNA in the CSF in single cases $[17,18]$. CSF examinations in COVID19-associated meningoencephalitis show pleocytosis with predominance of lymphocytes and increased 
concentration of protein, which typical for viral infections. This suggests active intrathecal inflammation [18]. In our patient result of CSF examination indicated bacterial etiology of neuroinfection.

Although classic abnormalities of CSF examination typically for bacterial meningitis was observed and $S$. pneumoniae was isolated from blood and bronchial wash, CSF culture was negative. Similar observations have been previously reported in literature [19]. Bohr et al. in the retrospective study in 875 patients diagnosed with bacterial meningitis, not pretreated with antibiotics, showed positive CSF culture in $85 \%$ cases [20]. In described case, a negative CSF culture could have been the result of using antibiotics before the lumbar puncture. The results of two large cohort studies confirmed a $4-18 \%$ decrease in culture positivity when empiric antibiotic therapy was administered prior to CSF sampling [20, 21].

Based on the studies conducted so far, it has been proven that viruses may promote the development of severe invasive bacterial infections, including meningitis, in selected patients [5, 6].

Klein et al. study concluded that bacterial co-infection should be considered in differential diagnosis in all patients hospitalized with influenza, but not all patients are co-infected. The predominant co-infecting organism was S. pneumoniae followed by Staphylococcus aureus. Bacterial co-infection is associated with more severe symptoms and higher mortality [7].

Identified bacterial or fungal co-infections among COVID-19 patients are not so common. Langford et al. meta-analysis estimated the presence of co-infections in $8.6 \%$ of over 30,000 analyzed patients [8]. Also Palanisamy et al. reported secondary bloodstream infections in 8.5\% COVID-19 ICU patients [22]. Similar findings was proved in Rawson's study of eighteen full texts reporting bacterial/fungal co-infection. Furthermore, they highlighted wide use of broad-spectrum antibiotics, despite the lack of microbiological confirmation of bacterial co-infection [9]. Low rates of bacterial and fungal infection in COVID-19 patients were also reported from Spain and United Kingdom. Bacterial and fungal co-infections and superinfections in these countries were estimated at $3 \%$ and $6 \%$, respectively [10].

Tocilizumab increases the risk of opportunistic and serious bacterial infection [23]. In patients 65 years of age or older, receiving doses of $8 \mathrm{mg} / \mathrm{kg}$, the incidence rates of infections reach 8.5 episodes per 100 patientyears. Other tocilizumab-related infection risk factors are coexisting lung disease and corticosteroid therapy [24]. Therefore, regular clinical assessment of patients treated with anti-IL-6 agents is essential for the early diagnosis of developing infection [23].
In presented case, temporary improvement in general condition was achieved after implementation of targeted on cytokine storm treatment (tocilizumab plus dexamethasone), typical for the late phase of COVID19. Pneumococcal pneumoniae, sepsis and meningitis were diagnosed during hospitalization, although no symptoms of invasive infection were found upon admission to the hospital. The course of co-infection with the SARS-CoV-2 and S. pneumoniae was life-threatening. The implemented antibiotic therapy, despite S. pneumoniae sensitivity to ceftriaxone (MIC $\leq 0.12 \mu \mathrm{g} / \mathrm{ml}$ ), did not result in recovery. The patient died on the 5th day after the onset of pneumococcal infection.

Based on our experience we concluded, that coinfections with bacterial pathogens appear to be not common among COVID-19 patients, but may cause a sudden deterioration of the general condition. Not only vascular neurological complications, but also meningitis should be always considered in patients with sudden disturbances of consciousness. Anti-inflammatory treatment with the combination of corticosteroids and tocilizumab (or tocilizumab alone) pose a severe risk for secondary lethal bacterial or fungal infections. Thus, treating a high-risk population (i.e. elderly) with these anti-inflammatory agents, require daily clinical assessment, regular monitoring of CRP and procalcitonin, as well as standard culture of blood, urine and sputum in order to detect concomitant infections, as rapidly as possible.

\section{Abbreviations}

COVID-19: Coronavirus disease-2019; CRP: C-reactive protein; CSF: Cerebrospinal fluid; CT: Computed tomography; ICU: Intensive care unit; IL-6: Interleukin 6; MERS-CoV: Middle East respiratory syndrome coronavirus; MIC: Minimum inhibitory concentration; PCR: Polymerase chain reaction; PCT: Procalcitonin; SABA: Short acting beta agonists; SAMA: Short acting muscarinic antagonist; SARS-CoV-2: Severe acute respiratory syndrome coronavirus-2.

\section{Acknowledgements}

Not applicable.

\section{Authors' contributions}

KG, AMM, PC analyzed and prepared the data, wrote the manuscript; EKZM was the leading doctor; $K G$ was involved in the clinical management of the patient. Our manuscript reporting adheres to CARE guidelines. All authors read and approved the final manuscript.

\section{Funding}

No founding.

Availability of data and materials

The raw data can be requested from Corresponding Author: kguziejko@wp.pl.

\section{Declarations}

Ethics approval and consent to participate Not applicable. 


\section{Consent for publication}

Written informed consent was obtained from the relative of the patient for publication of this case report and any accompanying images. A copy of the written consent is available for review by the Editor of this journal.

\section{Competing interests}

The authors declare no competing interests.

\section{Author details}

'2nd Department of Lung Diseases and Tuberculosis, Medical University of Bialystok, Żurawia 14, 15-540 Białystok, Poland. ${ }^{2}$ Department of Infectious Diseases and Neuroinfections, Medical University of Białystok, Żurawia 14, 15-540 Białystok, Poland. ${ }^{3}$ Observation and Infectious Department, Independent Public Healthcare Center in Bielsk Podlaski, ul. Kleszczelowska 1 17-100 Bielsk Podlaski, Poland.

Received: 11 January 2022 Accepted: 15 February 2022

Published online: 23 February 2022

\section{References}

1. Wiersinga WJ, Rhodes A, Cheng AA, et al. Pathophysiology, transmission, diagnosis, and treatment of coronavirus disease 2019 (COVID-19): a review. JAMA. 2020;324(8):782-93. https://doi.org/10.1001/jama.2020. 12839.

2. Chams N, Chams S, Badran R, Shams A, Araji A, et al. COVID-19: a multidisciplinary review. Front Public Health. 2020;29(8):383. https://doi.org/10. 3389/fpubh.2020.00383.

3. Loughran AJ, Orihuela CJ, Tuomanen El. Streptococcus pneumoniae: invasion and inflammation. Microbiol Spectr. 2019. https://doi.org/10.1128/ microbiolspec.GPP3-0004-2018

4. Oordt-Speets AM, Bolijn R, van Hoorn RC, Bhavsar A, Kyaw MH. Global etiology of bacterial meningitis: a systematic review and meta-analysis. PLoS ONE. 2018;13(6): e0198772. https://doi.org/10.1371/journal.pone. 0198772.

5. Robinson KM, Kolls JK, Alcorn JF. The immunology of influenza virusassociated bacterial pneumonia. Curr Opin Immunol. 2015;34:59-67. https://doi.org/10.1016/j.coi.2015.02.002 (Epub 2015 Feb 24).

6. Rynda-Apple A, Robinson KM, Alcorn JF. Influenza and bacterial superinfection: illuminating the immunologic mechanisms of disease. Infect Immun. 2015;83(10):3764-70. https://doi.org/10.1128/IAl.00298-15.

7. Klein EY, Monteforte B, Gupta A, Jiang W, May L, et al. The frequency of influenza and bacterial coinfection: a systematic review and meta-analysis. Influenza Other Respir Viruses. 2016;10(5):394-403. https://doi.org/10. 1111/irv.12398 (Epub 2016 Jun 24)

8. Langford BJ, So M, Raybardhan S, Leung V, Soucy J-PR, et al. Antibiotic prescribing in patients with COVID-19: rapid review and meta-analysis. Clin Microbiol Infect. 2021;27(4):520-31. https://doi.org/10.1016/j.cmi. 2020.12.018 (Epub 2021 Jan 5).

9. Rawson TM, Moore LS, Zhu N, Ranganathan N, Skolimowska K, et al. Bacterial and fungal coinfection in individuals with coronavirus: a rapid review to support COVID-19 antimicrobial prescribing. Clin Infect Dis. 2020;71(9):2459-68. https://doi.org/10.1093/cid/ciaa530.

10. Rawson TM, Wilson RC, Holmes A. Understanding the role of bacterial and fungal infection in COVID-19. Clin Microbiol Infect. 2021;27(1):9-11. https://doi.org/10.1016/j.cmi.2020.09.025 (Epub 2020 Oct 9).

11. Harapan BN, Yoo HJ. Neurological symptoms, manifestations, and complications associated with severe acute respiratory syndrome coronavirus 2 (SARS-CoV-2) and coronavirus disease 19 (COVID-19). J Neurol. 2021;268(9):3059-71. https://doi.org/10.1007/s00415-021-10406-y.

12. Keyhanian K, Umeton RP, Mohit B, Davoudi V, Hajighasemi F, et al. SARSCoV-2 and nervous system: from pathogenesis to clinical manifestation. J Neuroimmunol. 2020;7(350): 577436. https://doi.org/10.1016/j.jneuroim. 2020.577436.

13 Ahmed MU, Hanif M, Jamat Ali MJ, Haider MA, Kheran D, et al. Neurological manifestations of COVID-19 (SARS-CoV-2): a review. Front Neurol. 2020;22(11):518. https://doi.org/10.3389/fneur.2020.00518.

14 Brueggemann AB, Jansen van Rensburg MJ, Shaw D, McCarthy ND, Jolley $K A$, et al. Changes in the incidence of invasive disease due to Streptococcus pneumoniae, Haemophilus influenzae, and Neisseria meningitidis during the COVID-19 pandemic in 26 countries and territories in the invasive respiratory infection surveillance initiative: a prospective analysis of surveillance data. Lancet Digit Health. 2021;3(6):e360-70. https://doi. org/10.1016/S2589-7500(21)00077-7.

15. Lau KK, Yu WC, Chu CM, Lau ST, Sheng B, et al. Possible central nervous system infection by SARS coronavirus. Emerg Infect Dis. 2004;10(2):342. https://doi.org/10.3201/eid1002.030638.

16. Katal S, Balakrishnan S, Gholamrezanezhad A. Neuroimaging and neurologic findings in COVID-19 and other coronavirus infections: a systematic review in 116 patients. J Neuroradiol. 2021;48(1):43-50. https://doi.org/ 10.1016/j.neurad.2020.06.007.

17. Moriguchi T, Harii N, Goto J, Harada D, Sugawara H, et al. A first case of meningitis/encephalitis associated with SARS-coronavirus-2. Int J Infect Dis. 2020;94:55-8. https://doi.org/10.1016/j.ijid.2020.03.062.

18. Mondal R, Ganguly U, Deb S, Shome G, Pramanik S, et al. Meningoencephalitis associated with COVID-19: a systematic review. J Neurovirol. 2021;27(1):12-25. https://doi.org/10.1007/s13365-020-00923-3.

19. van de Beek D, Cabellos C, Dzupova O, Esposito S, Klein M, Kloek AT, ESCMID Study Group for Infections of the Brain (ESGIB), et al. ESCMID guideline: diagnosis and treatment of acute bacterial meningitis. Clin Microbiol Infect. 2016;22(Suppl 3):S37-62. https://doi.org/10.1016/j.cmi. 2016.01.007.

20 Bohr V, Rasmussen N, Hansen B, Kjersem H, Jessen O, et al. 875 cases of bacterial meningitis: diagnostic procedures and the impact of preadmission antibiotic therapy. Part III of a three-part series. J Infect. 1983;7:193-202.

21. Nigrovic LE, Malley R, Macias CG, Kanegaye JT, Moro-Sutherland DM, et al. Effect of antibiotic pretreatment on cerebrospinal fluid profiles of children with bacterial meningitis. Pediatrics. 2008;122:726-30. https:// doi.org/10.1542/peds.2007-3275.

22. Palanisamy N, Vihari N, Meena DS, Kumar D, Midha N, et al. Clinical profile of bloodstream infections in COVID-19 patients: a retrospective cohort study. BMC Infect Dis. 2021;21(1):933. https://doi.org/10.1186/ s12879-021-06647-x.

23. Winthrop KL, Mariette X, Silva JT, Benamu E, Calabrese LH, et al. ESCMID Study Group for Infections in Compromised Hosts (ESGICH) consensus document on the safety of targeted and biological therapies: an infectious diseases perspective (Soluble immune effector molecules [II]: agents targeting interleukins, immunoglobulins and complement factors). Clin Microbiol Infect. 2018;24(Suppl 2):S21-40. https://doi.org/10. 1016/j.cmi.2018.02.002.

24. Schiff MH, Kremer JM, Jahreis A, Vernon E, Isaacs JD, et al. Integrated safety in tocilizumab clinical trials. Arthritis Res Ther. 2011;13:R141.

\section{Publisher's Note}

Springer Nature remains neutral with regard to jurisdictional claims in published maps and institutional affiliations.

Ready to submit your research? Choose BMC and benefit from

- fast, convenient online submission

- thorough peer review by experienced researchers in your field

- rapid publication on acceptance

- support for research data, including large and complex data types

- gold Open Access which fosters wider collaboration and increased citations

- maximum visibility for your research: over $100 \mathrm{M}$ website views per year

At BMC, research is always in progress.

Learn more biomedcentral.com/submissions 